ORIGINAL ARTICLE

\title{
THE IMPACT OF LONGER WORKING TO MERCURY LEVEL (HG) IN BLOOD OF THOSE TRADITIONAL GOLD MINERS AT DESA PANTON LUAS KABUPATEN ACEH SELATAN
}

\author{
Syafruddin \\ Faculty of Medicine, Uni versity of Sumatera Utara \\ *Corresponding Author: Din95697@gmail.com
}

\begin{abstract}
It is seen traditional gold mining workings where there use mercury to process out amalgamation has been done for more than 4 years already at Desa Panton Luas. This paper is to determine the impact of longer work with Mercury level existed in the blood of those mining workers with traditional gold miners on the location. This paper is descriptive research and found that the mercury level existed in blood for a working period of average a year noted $5.57 \mathrm{ppb}$, for 2 years average noted $6.52 \mathrm{ppb}$, in three years average $7.34 \mathrm{ppb}$, and for 4 years average noted $8.95 \mathrm{ppb}$. As has been conducted in statistical test analysis indicated that there is a difference between a long-time off work in a year to 4 years serving with $\mathrm{p}<0.05$. Still, an existing difference of increasing mercury level in blood with a long time of one, two, three and four years serving in the field but it is threshold value as recommended by WHO namely 5-10 ppb.
\end{abstract}

Keywords: mercury blood level, long duration of working, gold mining

\section{INTRODUCTION}

The use of mercury in gold mining activities has been carried out. Improper use and management will have a detrimental impact on both workers, the environment and surrounding communities. The detrimental effects of mercury have become a major topic in the world since the emergence of the Minamata case in Japan. Exactly when a mental illness and neurological disorder (Minamata disease) is found that affects people living around Minamata Bay in Japan. This fact then becomes the trigger of the problems of environmental pollution to the surface of the international world.

The events of mercury poisoning around the world are known at the beginning of the era of 1953-1960 in Minamata-Japan with the number of cases 111 people died, in Iraq occurred in 1961 with the number of cases 35 people died and 321 people were injured, in West Pakistan occurred in 1963 with the number cases of 4 people died and 34 people were injured, in Guatemala occurred in 1966 with the number of cases 20 people died and 45 people 
were injured, and in Nigeria-Japan occurred in 1968 with the number of cases 5 people died and 25 people injured. ${ }^{1}$

Cases of mercury poisoning in the population in Indonesia occur in several places, for example, the case of Buyat bay as a result of pollution from the gold mining of PT. Newmont and unlicensed gold mining activities are polluting several riverbanks in Central Kalimantan. An examination conducted on residents living around Buyat bay found mercury content in the blood that exceeds the Threshold Value. ${ }^{2}$

Meanwhile, gold mining in Panton Luas Village was carried out without permission from the local government or better known as Mining Gold without Permits which is a community mining that has been going on for four years. The gold mining activities are carried out in traditional ways, simple techniques, without good planning, with low technology, improvised equipment and do not use personal protective equipment such as gloves, shoes, and masks.

As is known that mercury $(\mathrm{Hg})$ is one of the heavy metal elements that get the main attention in terms of health because the use of mercury as an ingredient to separate gold from other metals, causing environmental pollution and is toxic to humans. ${ }^{3}$

Gold miners are generally exposed to mercury through direct skin contact, breathing in mercury vapors and mercury-contaminated food. For the general public, pollution usually occurs due to eating contaminated fish and breathing in mercury vapors from mining sites. ${ }^{4}$
Based on an examination at the Medan Environmental Health Engineering Center in February 2012, mercury levels in river water in Panton Luas Village obtained a value of $0.001 \mathrm{ppb}$ upstream, a water sample in the middle of $0.002 \mathrm{ppb}$, and a downstream water sample of $0.002 \mathrm{ppb}$, whereas a standard water quality standard of $0.001 \mathrm{ppb} .^{5}$ This has exceeded the water quality standard. Examination of mercury levels in water is done by the method of Inductively Coupled Plasma-Optic Emission Spectrometry (ICP-OES).

Based on the results of interviews with the community and related agencies showed that research on levels of mercury in the blood has never been done, this certainly can not find out the level of mercury exposure in the community, especially those working in panning, so research should be done to determine the impact of a long time working on mercury levels in the blood of workers in panning in Panton Luas Village.

\section{METHODS}

The design of this research is an analytic correlation with the design of the cross-sectional approach

Blood sampling was carried out in Panton Luas Village, Sawang District, South Aceh Regency. The sample preparation process was carried out at the USU Basic Sciences Laboratory (LIDA), while the analysis of mercury levels in blood samples was conducted at the Medan Environmental Health Engineering Center and the time of the study was conducted from January to March 2013. 
The population in this study were all traditional gold miners in Panton Luas Village, Sawang District, South Aceh Regency. The sample in this study were workers in the panning exposed to mercury during the amalgamation process. The sampling technique in this study was total sampling, in which samples were taken by 3 workers from each of the 10 panning places, so as to obtain a total sample of 30 people.

\section{RESULT}

The results of interviews with 30 respondents in panning workers in Panton Luas Village, where all were male and without using personal protective equipment (PPE).

Demographic data from the interviews were obtained from gold mine workers in Panton Luas Village, Sawang District, South Aceh Regency in Table 1.

Based on Table 1, there are data that the majority of gold mining workers aged between 31-40 years were 11 people $(36.7 \%)$ and the majority had an elementary school education of 18 people $(60 \%)$.

Table 1 Distribution of Age and Education Characteristics

\begin{tabular}{llll}
\hline No & $\begin{array}{l}\text { Worker age } \\
\text { (Years) }\end{array}$ & Frequency & $\begin{array}{c}\text { Percentage } \\
(\boldsymbol{\%})\end{array}$ \\
\hline 1 & $20-30$ & 7 & 23,3 \\
2 & $31-40$ & 11 & 36,7 \\
3 & $41-50$ & 9 & 30,0 \\
4 & $>51$ & 3 & 10,0 \\
\hline \multicolumn{3}{l}{ Education } & \\
\hline 1 & Elementary & 18 & 60,0 \\
& school & & 40,0 \\
2 & Junior high & 12 & \\
\hline & school & & \\
\hline
\end{tabular}

The results of the examination of blood mercury levels in gold mine workers in Panton Luas Village, Sawang District, South Aceh Regency with ICP-OES with a wavelength $(\lambda)$ of $253.6 \mathrm{~nm}$ were obtained as follows:

Table 2. Distribution of Mercury

\section{Levels in the Blood}

\begin{tabular}{|c|c|c|c|c|}
\hline No & $\begin{array}{l}\text { Blood } \\
\text { Mercury } \\
\text { Levels }\end{array}$ & $\begin{array}{l}\text { Work } \\
\text { duration } \\
\text { (year) }\end{array}$ & $\begin{array}{l}\text { Number } \\
\text { (person) }\end{array}$ & $\begin{array}{c}\text { Percen } \\
\text { tage } \\
(\%)\end{array}$ \\
\hline & & \multicolumn{3}{|l|}{1 year } \\
\hline 1 & 5,0 & & 1 & 3,3 \\
\hline 2 & 5,2 & & 2 & 6,7 \\
\hline 3 & 5,5 & & 1 & 3,3 \\
\hline 4 & 5,6 & & 1 & 3,3 \\
\hline 5 & 5,9 & & 3 & 10,0 \\
\hline \multicolumn{5}{|c|}{2 year } \\
\hline 6 & 6,1 & & 1 & 3,3 \\
\hline 7 & 6,2 & & 2 & 6,7 \\
\hline 8 & 6,4 & & 2 & 6,7 \\
\hline 9 & 6,7 & & 1 & 3,3 \\
\hline 10 & 6,8 & & 1 & 3,3 \\
\hline 11 & 6,9 & & 2 & 6,7 \\
\hline \multicolumn{5}{|c|}{3 year } \\
\hline 12 & 7,3 & & 1 & 3,3 \\
\hline 13 & 7,4 & & 2 & 6,7 \\
\hline 14 & 7,5 & & 1 & 3,3 \\
\hline 15 & 7,6 & & 1 & 3,3 \\
\hline 16 & 7,8 & & 1 & 3,3 \\
\hline \multicolumn{5}{|c|}{4 year } \\
\hline 17 & 8,6 & & 1 & 3,3 \\
\hline 18 & 8,9 & & 3 & 10,0 \\
\hline 19 & 9,0 & & 2 & 6,7 \\
\hline 20 & 9,4 & & 1 & 3,3 \\
\hline \multicolumn{3}{|c|}{ Total } & 30 & 100,0 \\
\hline
\end{tabular}

Table 2 shows that blood mercury levels in gold mining workers in Panton Luas village are low at $5.0 \mathrm{ppb}$ and the highest is 9.4 $\mathrm{ppb}$, while the highest frequency is $5.9 \mathrm{ppb}$ and $8.9 \mathrm{ppb}$.

Descriptive statistical test results of average blood mercury levels between one, two, three, and four years of service for gold mine workers in Panton Luas Village in Table 3 and Figure 1. 
Table 3. Changes in the Average Level of Mercury in the Blood with Length of Work

\begin{tabular}{ccccc}
\hline No & $\begin{array}{c}\text { 1 Year } \\
\text { (ppb) }\end{array}$ & $\begin{array}{c}\text { 2 Year } \\
\text { (ppb) }\end{array}$ & $\begin{array}{c}\text { 3 Year } \\
\text { (ppb) }\end{array}$ & $\begin{array}{c}\text { 4 Year } \\
\text { (ppb) }\end{array}$ \\
\hline 1 & 5,9 & 6,9 & 7,5 & 9,0 \\
2 & 5,5 & 6,9 & 7,6 & 8,9 \\
3 & 5,6 & 6,7 & 7,3 & 9,0 \\
4 & 5,9 & 6,8 & 7,4 & 9,4 \\
5 & 5,9 & 6,2 & 6,4 & 8,6 \\
6 & 5,2 & 6,1 & 7,8 & 8,9 \\
7 & 5,0 & 6,4 & 7,4 & 8,9 \\
8 & 5,2 & 6,2 & & \\
\hline$\overline{\mathbf{R}}$ & $\mathbf{5 , 5 7}$ & $\mathbf{6 , 5 2}$ & $\mathbf{7 , 3 4}$ & $\mathbf{8 , 9 6}$ \\
\hline
\end{tabular}

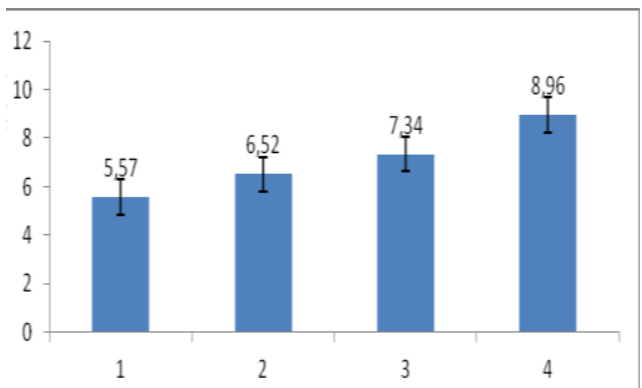

Figure 1. Changes in Average Levels of Mercury in The Blood of Gold Miners with Work Duration

Figure 1 shows that with one year of work from eight samples, the mean \pm standard deviation of blood mercury levels is $5.57 \mathrm{ppb}$ (SD \pm 0.40 ), with two years of work out of eight samples, the mean \pm standard deviation values mercury in the blood is $6.52 \mathrm{ppb}$ ( $\mathrm{SD} \pm 0.34)$, with three years of work out of seven samples there is a mean \pm standard deviation of mercury levels in the blood is 7.34 $\mathrm{ppb}(\mathrm{SD} \pm 0.45)$, with a long time of work Four years out of seven samples the mean \pm standard deviation of mercury in the blood was $8.96 \mathrm{ppb}$ $(\mathrm{SD} \pm 0.24)$.

Data from the Kruskal Wallis statistical test results in the average blood mercury level between the length of work for one, two, three, and four years in gold mine workers in Panton Luas Village can be seen in Table 4.

Table 4. Kruskal Wallis Statistical Test Results Blood Mercury Levels

\begin{tabular}{llll}
\hline $\begin{array}{c}\text { Work } \\
\text { Duration } \\
\text { (Year) }\end{array}$ & N & $\begin{array}{c}\text { Mercur } \\
\text { y Level } \\
\text { (Mean) }\end{array}$ & $\begin{array}{c}\mathbf{P} \\
\text { Value }\end{array}$ \\
\hline 1 & 8 & 5,06 & \\
2 & 8 & 12,25 & $\mathrm{P}=0,000$ \\
3 & 7 & 19,64 & $(\mathrm{p}<0,05)$ \\
4 & 7 & 27,00 & \\
\hline Total & $\mathbf{3 0}$ & & \\
\hline
\end{tabular}

Based on the results of the Kruskal Wallis statistical test it can be said that the average mercury in the blood shows a very significant difference when compared between the length of work for one, two, three and four years $(\mathrm{p}<0.05)$.

Data on the relationship of the respondent's weight to blood mercury levels in traditional gold mining workers in Panton Luas Village can be seen in Table 5 .

Table 5 The results of correlation tests between body weight and blood mercury levels show a value of $p=0.087$ or $p>0.05$, it can be concluded that there is no significant relationship between body weight and blood mercury levels.

Based on the data, the relationship between respondent's working hours and blood mercury levels in traditional gold mining workers in Panton Luas Village can be seen in Table 6 , that is, the test results show the value of $p=0.527$ or p> 0.05 , so it can be concluded that there is no relationship which is signed between long hours of work and blood mercury levels 
Table 5. Correlation of Body Weight to Blood Mercury Levels

\begin{tabular}{|c|c|c|c|}
\hline No & $\begin{array}{c}\text { Weight } \\
\text { (Kg) }\end{array}$ & $\begin{array}{c}\text { Blood } \\
\text { mercury } \\
\text { level (ppb) }\end{array}$ & $\begin{array}{c}\mathbf{P} \\
\text { Value }\end{array}$ \\
\hline 1 & 45 & 5,9 & \\
\hline 2 & 60 & 5,5 & \\
\hline 3 & 55 & 5,6 & \\
\hline 4 & 40 & 5,9 & \\
\hline 5 & 50 & 5,9 & \\
\hline 6 & 56 & 5,2 & \\
\hline 7 & 60 & 5,0 & \\
\hline 8 & 57 & 5,2 & \\
\hline 9 & 45 & 6,9 & \\
\hline 10 & 55 & 6,9 & \\
\hline 11 & 47 & 6,7 & \\
\hline 12 & 55 & 6,8 & \\
\hline 13 & 53 & 6,2 & \\
\hline 14 & 58 & 6,1 & $\mathrm{P}=0,087$ \\
\hline 15 & 52 & 6,4 & $(p>0,05)$ \\
\hline 16 & 60 & 6,2 & \\
\hline 17 & 62 & 7,5 & \\
\hline 18 & 54 & 7,6 & \\
\hline 19 & 45 & 7,3 & \\
\hline 20 & 60 & 7,4 & \\
\hline 21 & 70 & 6,4 & \\
\hline 22 & 56 & 7,8 & \\
\hline 23 & 64 & 7,4 & \\
\hline 24 & 53 & 9,0 & \\
\hline 25 & 45 & 8,9 & \\
\hline 26 & 61 & 9,0 & \\
\hline 27 & 61 & 9,4 & \\
\hline 28 & 58 & 8,6 & \\
\hline 29 & 57 & 8,9 & \\
\hline 30 & 57 & 8,9 & \\
\hline
\end{tabular}

Based on the amount of mercury used in blood levels of mercury in gold mine workers in Table 7 shows the value of $p=0.426$ or $p>0.05$, it can be concluded that there is no significant relationship between the amount of mercury use with blood mercury levels.
Table 6. Correlation of Long Work Hours per day to Blood Mercury Levels

\begin{tabular}{cccc}
\hline No & $\begin{array}{c}\text { Work } \\
\text { duration } \\
\text { per day }\end{array}$ & $\begin{array}{c}\text { Blood } \\
\text { mercury } \\
\text { level (ppb) }\end{array}$ & $\begin{array}{c}\text { P } \\
\text { Value }\end{array}$ \\
\hline 1 & 12 & 5,9 & \\
2 & 8 & 5,5 & \\
3 & 8 & 5,6 & \\
4 & 8 & 5,9 & \\
5 & 8 & 5,9 & \\
6 & 8 & 5,2 & \\
7 & 8 & 5.0 & \\
8 & 8 & 5,2 & \\
9 & 8 & 6,9 & \\
10 & 12 & 6,9 & \\
11 & 8 & 6,7 & \\
12 & 8 & 6,8 & \\
13 & 8 & 6,2 & \\
14 & 8 & 6,1 & $\mathrm{P}=0,527$ \\
15 & 8 & 6,4 & $(\mathrm{p}>0,05)$ \\
16 & 8 & 6,2 & \\
17 & 8 & 7,5 & \\
18 & 8 & 7,6 & \\
19 & 10 & 7,3 & \\
20 & 8 & 7,4 & \\
21 & 8 & 6,4 & \\
22 & 8 & 7,8 & \\
23 & 8 & 7,4 & \\
24 & 8 & 9,0 & \\
25 & 8 & 8,9 \\
26 & 8 & 9,0 & \\
27 & 12 & 9,4 & \\
28 & 8 & 8,6 & \\
29 & 8 & 8,9 & \\
30 & 8 & 8,9 & \\
\hline & & & \\
\hline
\end{tabular}


Table 7. Correlation of the Amount of Mercury Usage in Blood Mercury Levels in Gold Mine Workers

\begin{tabular}{|c|c|c|c|}
\hline No & $\begin{array}{c}\text { Total } \\
\text { Mercury } \\
\text { Usage per } \\
\text { day/ml }\end{array}$ & $\begin{array}{c}\text { Blood } \\
\text { Mercury } \\
\text { Levels (ppb) }\end{array}$ & $\begin{array}{c}\mathbf{P} \\
\text { Value }\end{array}$ \\
\hline 1 & 24 & 5.9 & \\
\hline 2 & 24 & 5.5 & \\
\hline 3 & 24 & 5.6 & \\
\hline 4 & 24 & 5.9 & \\
\hline 5 & 24 & 5.9 & \\
\hline 6 & 24 & 5.2 & \\
\hline 7 & 24 & 5.0 & \\
\hline 8 & 18 & 5.2 & \\
\hline 9 & 24 & 6.9 & \\
\hline 10 & 24 & 6.9 & \\
\hline 11 & 24 & 6.7 & \\
\hline 12 & 18 & 6.8 & \\
\hline 13 & 24 & 6.2 & \\
\hline 14 & 24 & 6.1 & $\mathrm{P}=0,426$ \\
\hline 15 & 24 & 6.4 & $(p>0,05)$ \\
\hline 16 & 24 & 6.2 & \\
\hline 17 & 24 & 7.5 & \\
\hline 18 & 24 & 7.6 & \\
\hline 19 & 24 & 7.3 & \\
\hline 20 & 18 & 7.4 & \\
\hline 21 & 18 & 6.4 & \\
\hline 22 & 24 & 7.8 & \\
\hline 23 & 24 & 7.4 & \\
\hline 24 & 24 & 9.0 & \\
\hline 25 & 24 & 8.9 & \\
\hline 26 & 24 & 9.0 & \\
\hline 27 & 24 & 9.4 & \\
\hline 28 & 24 & 8.6 & \\
\hline 29 & 24 & 8.9 & \\
\hline 30 & 18 & 8.9 & \\
\hline
\end{tabular}

\section{DISCUSSION}

Based on statistical tests (table 3 and figure 1) on workers in the panning who have worked for one year, the mean \pm standard deviation of mercury levels in the blood of eight people is $5.57 \mathrm{ppb}(\mathrm{SD} \pm 0.40)$. This shows the level of mercury in the blood with a year of work is still within the threshold value determined by WHO, which is between 5-10 ppb. The upper limit of non-toxic concentration of mercury in the blood in other provisions is generally around 3-4 ppb. Concentrations of mercury in the blood greater than 4 $\mathrm{ppb}$ are not expected in healthy adults and need a medical examination to assess the possibility of adverse health effects. ${ }^{6}$ Exposure to mercury through inhalation and skin in panning with a year of work has not shown any impact on increasing levels of mercury in the blood or not harmful to health.

Based on table 3 and figure 1 the statistical data on eight workers in the panning who have worked for two years shows the mean \pm standard deviation of mercury levels in the blood is $6.52 \mathrm{ppb}(\mathrm{SD} \pm 0.34)$. The results of this study indicate the length of work in two years for mercury levels in the blood is still within the threshold value determined by the WHO which is between $5-10$ ppb. According to Sugeng (2010), the average level of mercury in the blood of $57.63 \mathrm{ppb}$ with an average length of work of 9.39 years. $^{7}$ Whereas the research of Dutywati (1997) in Maywati (2011), the average mercury level in blood samples of workers in the panning $19.52 \mathrm{ppb}$ with an average length of work of 19 years. ${ }^{8}$ This difference in mercury levels in the blood proves that with a long time working in a place or area there is not always an increase in mercury levels in the blood when workers work in the open or there is the use of personal protective equipment (PPE). While Duty (1997) in Maywati (2011) where the length of work related to the length of contact with mercury until the annual. ${ }^{8}$ The longer the contact with mercury, the longer the amount of exposure.

Based on statistical tests on seven workers in the panning who had worked for three years, the mean \pm standard deviation of mercury levels in the blood was $7.34 \mathrm{ppb}$ (SD 
$\pm 0.45)$. The results of the study showed that three years of work on blood mercury levels were still within the threshold determined by WHO, which was between 5-10 ppb. According to Gustav (1994), blood levels of mercury less than $3 \mathrm{ppb}$ are still within the threshold value, values of 3-10 ppb of blood mercury levels need to be watched out and mercury levels in blood with values greater than $10 \mathrm{ppb}$, in the long run, can endanger health can not be ignored. ${ }^{9}$ For a long time, someone worked in panning and during that time the person was exposed to mercury. Because mercury is accumulative, the longer the person works, the greater the amount of mercury in the body. ${ }^{7}$

Based on statistical data on seven workers in the panning who have worked for four years, the mean value \pm standard deviation of mercury levels in the blood is $8.96 \mathrm{ppb}$ (SD \pm 0.24 ). The results of the study showed four years of work on blood mercury levels were still within the threshold value determined by $\mathrm{WHO}$, which is between 5-10 ppb. According to Michael, (2010), if there is no exposure at work, total blood mercury levels are less than $5 \mathrm{ppb}$ and less than $15 \mathrm{ppb}$ at the end of the workweek. ${ }^{10}$ Meanwhile, mercury levels between $5 \mathrm{ppb}$ to $15 \mathrm{ppb}$ are levels of mercury that need to be watched out for. ${ }^{11}$ Statement of Brunton, et al, (2011); Maywati, (2011), that several things could be a risk factor for mercury levels in the blood including the amount of mercury used, chemical form, route of entry, and duration of contact with mercury. 6,8

The accumulation of mercury in human tissues will correspond to the level of exposure along with the increasing time of one's exposure. The lowest level of mercury in the blood sample detected was in the group with one year of work, which was an average of $5.57 \mathrm{ppb}$ (SD \pm 0.40 ), two years averaging $6.52 \mathrm{ppb}$ $(\mathrm{SD} \pm 0.34)$, three years averaged $7.34 \mathrm{ppb}(\mathrm{SD} \pm 0.45)$, while higher levels of mercury in workers with four years of work averaged $8.96 \mathrm{ppb}$ (SD \pm 0.24 ), or blood mercury levels shows the difference between one year and two years, 17\%; between two years and three years $12.6 \%$; between three years and four years $21.9 \%$. While the statistical test in (table 4.4) shows the value $(\mathrm{p}<0.05)$ which means there is a difference in blood mercury levels between those who have worked for one year and four years. This is consistent with the results of previous studies where the longer work or exposure to mercury in gold mine workers, the higher levels of mercury in the blood. ${ }^{2}$ Mercury levels in each person's blood are different, this depends on the length of work and level of exposure. Long-term mercury exposure is the most exposure to people who work in panning. ${ }^{11}$ The results of this study are in accordance with the previous statement made by Palopo, (2008) in Maywati (2011) where the impact of the entry of mercury into the body usually appears within years.. ${ }^{8}$

Workers in the panning are exposed to mercury for a long time and long, where workers do not realize that every day they work to absorb the mercury vapor in small amounts gradually through the respiratory tract. Exposure to mercury through the skin is also in low amounts, so the effect of exposure is 
not felt. Little exposure will enter the blood circulation and accumulation is low, thus allowing levels of mercury in the blood of workers in the panning still within the threshold value, which is an average of between $5.57 \mathrm{ppb}$ $(\mathrm{SD} \pm 0.40)-8.96 \mathrm{ppb}(\mathrm{SD} \pm 0.24)$. Workers in the panning are often found to be long-term poisoning or chronic. $^{1}$ Meanwhile, according to Inswiasri (2011), levels of mercury in the urine and hair which are chronic exposure biomarkers, while levels of mercury in the blood are acutely exposed. ${ }^{12}$

The results showed that the relationship between body weight and blood mercury levels was not significant ( $p>0.05)$. Weight can affect the levels of mercury in the body, because people with normal body weight tend to have low blood mercury levels, in contrast to people who have lean body weight are more susceptible to mercury levels in the blood. ${ }^{13}$ Mercury has fat-soluble properties, so people who have high levels of fat in the body will affect the absorption of mercury in the body and the excretion of mercury from the body because excessive fat will be stored in the body's tissues as well as dissolved mercury in it. $^{2}$ While people who are overweight are more vulnerable to the dangers of toxic substances that enter the body, because the thickness of fat tissue that affects the speed of blood flow that causes toxins to stay longer in the body.

The length of working hours is related to the length of time the worker contacts with mercury in a day. The longer the contract duration, the longer the amount of exposure time. Long working hours of gold miners have exceeded the normal working hours limit that applies for 8 working hours a day with 5 working days or 40 hours per week. ${ }^{13}$

The results showed a relationship between long hours of work with mercury levels in the blood showed no significant value ( $p>$ $0.05)$. The results of this correlation show an insignificant relationship between working hours and blood mercury levels even though they exceed normal working hours. Meanwhile Wahyu, et al, (2008) obtained $\mathrm{p}$-value $=0.109$ or $\mathrm{p}>0.05$ meaning that there was no relationship between the length of work and blood levels of $\mathrm{Hg}$, however the longer the gold miners worked, the longer their duration for exposure to mercury, thus allowing greater absorption of mercury by the body through oral, dermal, or inhalation. ${ }^{14}$

The gold processing is done traditionally by the amalgamation process. Amalgamation is the process of mixing rocks that are considered to contain gold with mercury. This mercury is used by miners in gold processing, namely in panning activities. The mercury is liquid, then put into a container as much as $24 \mathrm{ml}$ per day and then put into trommel. Mercury is in the hands, and enter the body. In addition, the mercury evaporates and is inhaled by the respiratory tract so it enters the body. Miners do not realize that mercury can enter their bodies during the work process, both through the skin and breathing.

The correlation results obtained the relationship between the amount of mercury use with mercury levels in the blood is not significant 
(p> 0.05). This insignificant relationship is made possible by the level of direct contact with mercury only when pouring mercury on the material in the trommel and at the time of extortion, so the risk of contamination is smaller. This is reinforced by the study of Suparjan (2012) where the value of $p=0.283$ means that there is no significant relationship between the amount of mercury used with blood mercury levels. ${ }^{15}$ Maywati (2011), where a p value> 0.05 means that there is no relationship between the amount of mercury $(\mathrm{Hg})$ usage per day to blood $\mathrm{Hg}$ levels. ${ }^{8}$ According to Shea, et al, (2004), the limited use of mercury by gold miners into trommel allows blood levels of mercury to be within the threshold value. ${ }^{16}$ The insignificant relationship between this allows the level of direct contact with mercury only when pouring mercury on the material in the trommel and at the time of extortion, so the risk of contamination is smaller.

The results of the field survey revealed that the types of gold mining work in Panton Luas Village can be divided according to their activities including rock excavation, salting, and workers in panning. Panning workers are more at risk of being exposed to mercury than gold-digging workers. The panning worker does not close allowing the level of exposure to below, this is according to the statement of Suparjan (2012) where panning workers only come into contact with mercury when pouring mercury into the material in trommel and when extorting amalgamation so that the risk of contamination is smaller. ${ }^{15}$
The form of elemental mercury is very volatile and can be absorbed through the lungs, especially in panning workers, this is because panning workers do not wear masks when working. Inorganic and organic mercury uptake through the digestive tract by consuming river fish, sea fish, oysters and shrimp that have been exposed to mercury, while through the skin a little level of exposure. This is in accordance with the ATSDR statement, 1999; WHO, 2001 in Inswiasri (2008) where exposure to mercury can pass through the digestive tract, especially fish contaminated with mercury, air, and skin by not wearing masks and gloves as personal protective equipment. ${ }^{12}$ However, the results of the study indicate that the accumulation of blood mercury in workers in the panning is still within the threshold value.

\section{CONCLUSION}

There is a change in the level of mercury in the blood that works one year with an average value of $5.57 \mathrm{ppb}(\mathrm{SD} \pm 0.40)$, the average value of working two years $6.52 \mathrm{ppb}$ $(\mathrm{SD} \pm 0.34)$, the average value the average of three years working was $7.34 \mathrm{ppb}(\mathrm{SD} \pm 0.45)$ and the average value of working four years was 8.96 $\mathrm{ppb}$ (SD \pm 0.24). There was a difference between one, two, three and four years of exposure to mercury in the blood of workers in the panning ( $p$ <0.05). Weight, work hours, and the amount of mercury use did not significantly affect blood mercury levels in Panton Luas Village ( $p>$ $0.05)$.

Need further examination of mercury levels in blood, hair, and 
urine on workers in the panning for more than four years. It is necessary to check the mercury in the air, shellfish and river water to see the level of environmental damage around the mine. Examination of mercury levels in blood, hair, and urine in the community around the panning and gold rock extraction workers need to be done to see the mercury exposure in the community around the mining.

\section{REFERENCE}

1. Heryando Palar. 2008. Pencemaran dan Toksikologi Logam Berat. Penerbit: Rineka Cipta. hal 94-115

2. Andri DH., Anies dan Suharyo, H. 2011. Kadar Merkuri pada Rambut Masyarakat di Sekitar Penambangan Emas Tanpa Ijin. Media Medika Indonesia. 45(3):181-187.

3. Lu, CF. 2006. Toksikologi Dasar. Edisi Ke dua. UI Press

4. Trilianty Lestarisa. 2010. Faktor-Faktor yang Berhubungan dengan Keracunan Merkuri (Hg) pada Penambang Emas Tanpa Ijin (PETI) di Kecamatan Kurun Kabupaten Gunung Mas Kalimantan Tengah. Semarang: Universitas Diponegoro Semarang, Program Pascasarjana

5. SNI. 2009. Batas Maksimum Cemaran Logam Berat Dalam Pangan. 7387.

6. Brunton, L.L., Keith, L. Parker., Donald, K. Blumenthal and Iain, L. O. Buxton. 2011. Logam Berat dan Antagonis. Di dalam:
Goodman dan Gilman. Manual Farmakologi dan Terapi. Jakarta. Penerbit: EGC. hal 1081-1085.

7. Sugeng Rianto. 2010. Analisa Faktor-Faktor yang Berhubungan dengan Keracunan Merkuri pada Penambang Emas Tradisional di Desa Jendi Kecamatan Selogiri Kecamatan Wonogiri. Semarang: Universitas Diponegoro Semarang, Program Pascasarjana

8. Maywati Sri. 2011 Hubungan Beberapa Faktor Pekerjaan Dengan Kadar Merkuri (Hg) Dalam Darah Pekerja Penambang Emas di Dusun Karangpaningal Desa Karanglayung Kecamatan Karangjaya Kabupaten Tasikmalaya. FKM Unsil. hal 51-56.

9. Gustav A. Drasch. 1994. Mercury. In: Hans G. Seiler, Astrid Sigel, Helmut Sigel.Handbook on Metals in Clinical and Analytical Chemistry. Institute of Inorganic Chemistry. The University of Basel.

10. Michael J. Kosneet. 2010. Intoksikasi Logam Berat dan Kelator. Di dalam: Bertram G. Katzung. Farmakologi Dasar dan Klinik. Penerbit: Buku Kedokteran EGC. Edisi 10. hal 984-985.

11. World Health Organization (WHO). 2012. Mercury and Health. No.3.

12. Inswiasri dan Haryanto Kusnoputranto. 2008. Paradigma Kejadian Penyakit Pajanan Merkuri (Hg). 
Ekologi Kesehatan. Puslitbang Ekologi dan Status Kesehatan. 7(2):775-785.

13. Wardiyatun Siti, Eko Hartini. 2009. Faktor-Faktor Yang Berhubungan Dengan Kadar Merkuri Dalam Urine Pada Pekerja Tambang Emas di Desa Rengas Tujuh Kecamatan Tumbang Titi Kabupaten Ketapang Kalimantan Barat hal 132142.

14. Wahyu Widowati, Astiana Sastiono dan Raymond Jusuf. 2008. Efek Toksik Logam Pencemaran dan
Penanggulangan Pencemaran. Penerbit CV ANDI. Yogyakarta.

15. Suparjan Petasule. 2012. Faktor-faktor Yang Berhubungan Dengan Kejadian Keracunan Merkuri Pada Pemijar dan Pengolah Emas di Tambang Emas Desa Hulawa Kecamatan Sumalata Timur Kabupaten Gorontalo Utara. Jurusan Kesehatan Masyarakat, Fakultas IlmuIlmu Kesehatan dan Keolahragaan, Universitas Negeri Gorontalo. Hal 3-8 